\author{
Information \\ for Authors
}

\section{Avis aux auteurs}

The purpose of the Canadian Journal of Philosophy is the publication in Canada of philosophical work of high quality, in English or French, and in any field of philosophy. All submissions are given blind editorial review; those of departmental colleagues are externally refereed.

Four copies of submitted manuscripts, double-sided if preferred, should be sent to: Executive Secretary, Canadian Journal of Philosophy, University of Lethbridge, Lethbridge, Alberta, Canada T1K 3M4. It is preferred that manuscripts be typed double-spaced, including quotes and footnotes. In general, the Canadian Journal of Philosophy follows The University of Chicago Manual of Style. Footnotes should be numbered consecutively and assembled on separate pages at the end of the manuscript. Manuscripts should be prepared for blind review, which means they should contain no self-identifying references in either text or footnotes. Manuscripts will not be returned unless return postage is prepaid by cheque, money-order, reply coupons, or Canadian stamps.

Authors will receive, without charge, 25 copies of their articles. Additional offprints may be ordered when the proofs are returned to the publisher.

The articles in CJP are indexed in The Philosophers' Index, Bowling Green, Ohio, USA, the Répertoire bibliographique de la philosophie, Louvain, Belgium, The Modern Language Association Directory of Periodicals, the Humanities Index, the International Bibliography of the Social Sciences, and the Canadian Periodical Index.

All enquiries of an editorial nature should be directed to the Executive Secretary at the above address.

The Canadian Journal of Philosophy a pour objet la publication canadienne, en langues anglaise ou française, d'études philosophiques de haut niveau, quel que soit le domaine philosophique auxquelles elles appartiennent. Les communications sont évaluées dans l'anonymat de leurs auteurs; celles que soumettent les collègues départementaux sont référées à un comité de lecture extérieur.

Les manuscrits, en quatre exemplaires, doivent être adressés à La Secrétaire à la Rédaction. Canadian Journal of Philosophy, University of Lethbridge, Lethbridge, Alberta, Canada T1K 3M4. Soumettre de préférence des manuscrits (citations et notes comprises) dactylographiés à double interligne, en prenant pour guide, dans la mesure du possible, The University of Chicago Manual of Style. Les notes doivent suivre la numérotation continue et figurer sur des feuilles indépendantes en annexe au manuscrit. Les manuscrits devraient être préparé pour l'évaluation anonyme par les pairs. Il ne doit pas par conséquent contenir aucune référence, que ce soit dans le texte ou dans les notes, qui pourrait servir à identifier l'auteur. Les textes non insérés ne sont rendus qu'en cas de prépaiement des frais de poste par chèque, mandat, coupons-réponse, ou timbres canadiens.

Les auteurs recoivent gratuitement 25 tirés-à part de leur article. Ils sont priés, s'ils désirent en obtenir un plus grand nombre à titre onéreux, en informer l'imprimeur lors de renvoi des épreuves.

Les articles du CJP sont catalogués dans The Philosophers' Index, Bowling Green, Ohio, E-U, le Répertoire bibliographique de la philosophie, Louvain, Belgique, The Modern Language Association Directory of Periodicals, Humanities Index, International Bibliography of the Social Sciences et l'Index de Périodiques Canadiens. 
Subscription Information
Canadian Journal of Philosophy is published by the University of Calgary Press.

Canadian Journal of Philosophy is published quarterly, in March, June, September, and December. In addition to these regular issues, CJP publishes annually a supplementary volume of original papers on a selected theme of contemporary philosophical interest. This supplementary volume is free to all subscribers to the journal in that year. Supplementary volumes may also be purchased separately from Raincoast Books, 8680 Cambie St., Vancouver, BC V6P 6M9.

Correspondence regarding subscriptions, renewals, and single issues should be addressed to Canadian Journal of Philosophy c/o University of Calgary Press, The University of Calgary, Calgary, Alberta, Canada T2N 1N4.

A subscription for the 2000 volume of four issues plus the supplementary volume is:

$\begin{array}{lrr} & \text { Canada } & \text { Outside Canada } \\ \text { Institutions } & \text { Cdn. } \$ 50.00 & \text { US } \$ 50.00 \\ \text { Individuals } & 25.00 & 25.00 \\ \text { Students } & 15.00 & 15.00 \\ \text { Single issues } & 9.00 & 9.00\end{array}$

Subscribers to the Canadian Journal of Philosophy are eligible for a discounted subscription to the Australasian Journal of Philosophy, as are Australasian Journal subscribers to the Canadian Journal. For information contact the University of Calgary Press as below.

\section{DCanadian Q. Journal of Philosophy}

University of Calgary Press

The University of Calgary

CALGARY, Alberta, Canada T2N 1N4

403-220-7736 Fax 403-282-0085

Email: wgee@ucalgary.ca
2000 Subscription Individual

Student

Institution

Canadian residents add $7 \%$ GST

TOTAL $\$$

Please send me information on CJP Supplementary Volumes $\square$

Name

Address

City

Country Postal Code

Visa $\square \quad$ Mastercard $\square \quad$ No.

$$
\text { Expiry Date }
$$

Cheques should be made payable to University of Calgary Press. 
Abonnements
Canadian Joumal of Philosophy est publié par University of Calgary Press.

Canadian Journal of Philosophy est une publication trimestrielle paraissant en mars, juin, septembre, et décembre. Outre ses quatre fascicules réguliers, il publie, annuellement, un supplément thématique d'articles inédits consacrés à des sujets d'actualité philosophique. Le supplément est offert gratuitement à tout abonné de l'année courante. Les suppléments sont également disponibles à titre onéreux à Raincoast Books, 8680 Cambie St., Vancouver, BC V6P 6M9.

Toute correspondance concernant l'administration (abonnements, renouvellements, commandes de numéros) doit être adressée à Canadian Journal of Philosophy, c/o University of Calgary Press, The University of Calgary, Calgary, Alberta, Canada T2N 1 N4.

Tarifs d'abonnement au volume 2000 (4 fascicules et de suppléments):

$\begin{array}{lrr} & \text { Canada } & \text { Hors-Canada } \\ \text { Institutions } & \text { Cdn. 50,00\$ } & \text { US 50,00\$ } \\ \text { Individus } & 25,00 \$ & 25,00 \$ \\ \text { Etudiants } & 15,00 \$ & 15,00 \$ \\ \text { Numéro simple } & 9,00 \$ & 9,00 \$\end{array}$

Lesabonnés de Canadian Joumal of Philosophypeuventbénéficierd'un rabais pour l'abonnement à l'Australasian Journal of Philosophy. Les abonnés de cette dernière revue peuvent eux aussi bénéficier d'un rabais pour Canadian Journal of Philosophy. Pour de plus amples renseignements, prière de contacter les Presses de l'Université de Calgary à l'adresse indiquée ci-bas.



Veuillez me faire parvenir tous les renseignements concernant les suppléments du $C J P$

Nom

Adresse

Ville

Pays Code Postal

Visa $\square \quad$ Mastercard $\square \quad$ No.

Date d'expiration

Libeller tout chèque à l'ordre de University of Calgary Press. 


\author{
Other \\ Business \\ Information
}

\section{Automatic \\ Permission \\ to Reproduce}

\section{Back Issues}

Services
administratifs
- détails
supplémen-
taires

\section{Reproduction affranchie d'agrément préalable}

\section{Volumes antérieurs}

All business correspondence should be addressed to Canadian Journal of Philosophy, University of Calgary Press, Calgary, Alberta T2N 1N4. This includes enquiries concerning advertising and promotion, exchanges, and reprinting. The copyright for all materials appearing in the regular issues and in the supplements of this journal is held by the Canadian Journal of Philosophy, and consent for any reproduction or reprinting must be obtained with the following exception.

Permission to reproduce parts of individual numbers of Canadian Journal of Philosophy by photocopy, xerox, offset, etc., for scholarly purposes (but not for republishing by printing nor for sale to the public) is automatically granted without prior permission being secured at the following rates: first 5 copies, no charge; 5 cents for each copy in excess of five of each page of CIP.

Remuneration is to be paid to the Canadian Journal of Philosophy, stating title and author of the article and number of copies. Proceeds above $\$ 10.00$ from any one article will be shared with the author. This announcement applies retroactively to volume I, number 1 .

Canadian Journal of Philosophy is indexed in Canadian Magazine Index by Micromedia Limited.

Toute correspondance administrative, à l'exception de celle qui concerne les abonnements, renouvellements et commandes de numéros et de suppléments, doit être adressée aux Canadian Journal of Philosophy, University of Calgary Press, Calgary, Alberta T2N $1 \mathrm{~N} 4$. Ecrire à l'adresse ci-dessus pour tous renseignements relatifs à la publicité et à la promotion, ainsi qu'aux échanges et aux réimpressions. Le copyright des articles afférents aux fascicules et suppléments est propriété du Canadian Journal of Philosophy. Leur reproduction ou rêimpression en tout ou partie ne peut être faite sans l'agrément préalable de le Directeur de la Publication, sauf dans le cas suivant.

Est affranchie d'agrément préalable la reproduction partielle des numéros du Canadian Journal of Philosophy par procédé technique de photocopie, xerox, offset, etc., lorsqu'elle vise exclusivement à des fins ou à des recherches académiques. Est interdite toute réimpression ayant pour objet la vente au public. Conditions tarifaires de reproduction: $1-5$ copies, accordé à titre gracieux; 6 copies ou en plus, 5 cents pour chaque copie de chaque page du CJP.

Effectuer tout règlement à l'ordre du Canadian Journal of Philosophy. Avoir soin d'indiquer le nom de l'auteur et le titre de l'article à reproduire $d$ 'une part, et le nombre de copies requises, de l'autre. Les apports provenant d'un article sont partagés à égalité avec son auteur pour la part numéraire dépassant $\$ 10.00$ (règlement rétroactif au volume I, No. 1 ).

Canadian Joumal of Philosophy est répertoirié par Micromedia ltée dans le Canadian Magazine Index. 


\section{CANADIAN JOURNAL OF PHILOSOPHY SUPPLEMENTARY VOLUMES}

\begin{tabular}{|c|c|c|c|c|}
\hline & & & $\begin{array}{l}\text { Retail } \\
\text { in } \\
\text { Canada } \\
\text { Cdn. } \$ \$\end{array}$ & $\begin{array}{c}\text { Retail } \\
\text { outside } \\
\text { Canada } \\
\text { US } \$ \$\end{array}$ \\
\hline \multirow[t]{4}{*}{ Vol. I } & -1975 & Part 1: New Essays in the & & \\
\hline & & History of Philosophy & 10.00 & 10.00 \\
\hline & & Part 2: New Essays in the & & \\
\hline & & Philosophy of Mind & 10.00 & 10.00 \\
\hline \multirow{2}{*}{$\begin{array}{l}\text { Vol. III } \\
\text { Vol. IV }\end{array}$} & -1977 & New Essays in Contract Theory & 13.00 & 13.00 \\
\hline & -1978 & New Essays in Rationalism & & $12 \Omega 0$ \\
\hline \multirow{2}{*}{ Vol. V } & -1979 & $\begin{array}{l}\text { and Empiricism } \\
\text { New Essays on Mill and }\end{array}$ & 13.00 & 13.00 \\
\hline & & Utilitarianism & 13.00 & 13.00 \\
\hline \multirow[t]{2}{*}{ Vol. VI } & -1980 & New Essays in Philosophy of & & \\
\hline & & Language & 13.00 & 13.00 \\
\hline Vol. VII & -1981 & Marx and Morality & 15.00 & 15.00 \\
\hline \multirow{2}{*}{ Vol. VIII } & -1982 & New Essays in Ethics and & & \\
\hline & & Public Policy & 14.00 & 13.00 \\
\hline Vol. IX & -1983 & New Essays on Plato & 13.00 & 13.00 \\
\hline Vol. X & -1984 & New Essays on Aristotle & 14.00 & 14.00 \\
\hline Vol. XI & -1985 & New Essays in the Philosophy & 1400 & 14 \\
\hline \multirow{2}{*}{ Vol. XII } & -1986 & $\begin{array}{l}\text { Of Mima, Series } 11 \\
\text { Nuclear Weapons, Deterrence }\end{array}$ & 14.00 & 14.00 \\
\hline & & and Disarmament & 12.00 & 10.00 \\
\hline \multirow[t]{2}{*}{ Vol. XIII } & -1987 & Science, Morality and & & \\
\hline & & Feminist Theory & 14.00 & 12.00 \\
\hline Vol. XTV & -1988 & Philosophy and Biology & 14.00 & 12.00 \\
\hline Vol. XV & -1989 & Analyzing Marxism & 25.00 & 21.00 \\
\hline Vol. XVI & -1990 & Canadian Philosophers - & & \\
\hline \multirow{3}{*}{ Vol. XVII } & & $\begin{array}{l}\text { Celebrating Twenty Years of the } \\
\text { Canadian Journal of Philosophy }\end{array}$ & 24.00 & 20.00 \\
\hline & -1991 & Aristotle and his Medieval & & \\
\hline & & Interpreters & 21.00 & 21.00 \\
\hline Vol. XVIII & -1992 & Return of the A Priori & 22.00 & 22.00 \\
\hline Vol. XIX & -1993 & Méta-Philosophie & 30.00 & 30.00 \\
\hline Vol. $X X$ & -1994 & Biology \& Society & 30.00 & 30.00 \\
\hline Vol. XXI & -1995 & On the Relevance of Metaethics & 24.00 & 24.00 \\
\hline Vol. XXII & -1996 & Rethinking Nationalism & 30.00 & 30.00 \\
\hline Vol. XXIII & -1997 & Meaning and Reference & 20.00 & 20.00 \\
\hline Vol. XXIV & -1998 & Pragmatism & 22.00 & 22.00 \\
\hline Vol. XXV & -1999 & Civilization and Oppression & 22.00 & 22.00 \\
\hline
\end{tabular}

Postage and Handling (Canada/U.S.A.) is $\$ 5.00$ (1-3 books). Postage and Handling (outside Canada) is $\$ 9.00$.

Canadian orders must include $7 \%$ GST on the total cost of the book(s) as well as the postage and handling.

Prices outside Canada are in US dollars.

Order University of Calgary Press

From: c/o Raincoast Distribution Services 9050 Shaughnessy Street

Fax Orders:

1-800-565-3770

Vancouver, BC V6P6E5

Email: custserv@raincoast.com 


\section{UNIVERSITY OF CALGARY PRESS

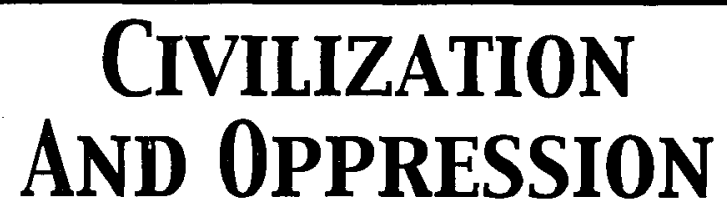 \\ edited by Catherine Wilson}

Canadian Journal of Philosophy, Suppi. Volume XXV $\$ 22.00$ - 294pp. • ISBN 0-919491-25-1 • ISSN 0229-7051

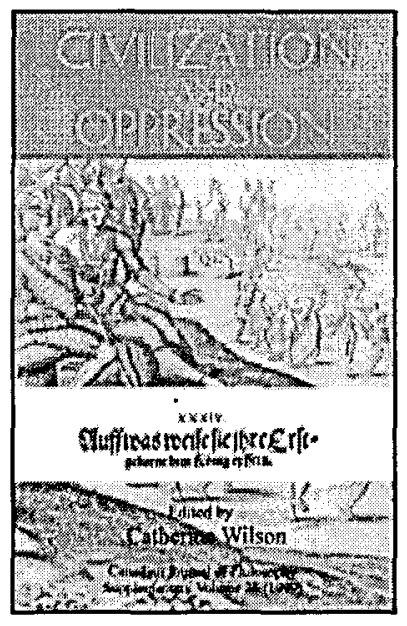

This distinctive collection of essays explores the relationship between the growth and development of civilization and the forms of social and political oppression that civilization permits and encourages as well as the forms of oppression that civilized societies unmask and seek to relieve. It offers fresh insights into the thought of political philosophers, including Locke, Montesquieu, Marx, Kant, Mill, and Rawls as well as the postmodernist response of Foucault and his successors to the fact of the domination of human by human.

Table of Contents

- Introduction - Social Inequality: Rousseau in Retrospect Catherine Wilson

- Lockean Money, Indigenism and Globalism Naomi Zack

- Vico and Montesquieu: Limits of Pluralist Imagination Bhikhu Parekh

- Millian Liberalism and Colonial Oppression D.G. Brown

- $\quad$ Sublime Waste: Kant on the Destiny of the 'Races' Mark Larrimore

- Time, Modernity, and Destructive Habits of Thought Oliver Leaman

- Subjecthood and Self-Determination: The Limitations of Postmodernism as Democratic Theory Jeff Noonan

- Justice Theory and Oppression J. Harvey

- Epistemic Oppression and Epistemic Privilege Miranda Fricker

- Freud's Metapsychology and the Culture of Philosophy Jan Zwicky

- A Singular and Representative Life: Personal Memory and Systematic Harms Sue Campbell

\section{Order from:}

\section{Raincoast Distribution Services}

9050 Shaughnessy Street, Vancouver, BC, V6P 6E5

Telephone: 1-800-663-5714 Fax: 1-800-565-3770

E-mail: custserv@raincoast.com






\section{UNIVERSITY OF CALGARY PRESS}

\section{PRAGMATISM}

edited by C.J. Misak

Canadian Journal of Philosophy, Suppl. Volume XXIV $\$ 22.00$ • 300pp. • ISBN 0-919491-24-3 • ISSN 0229-7051

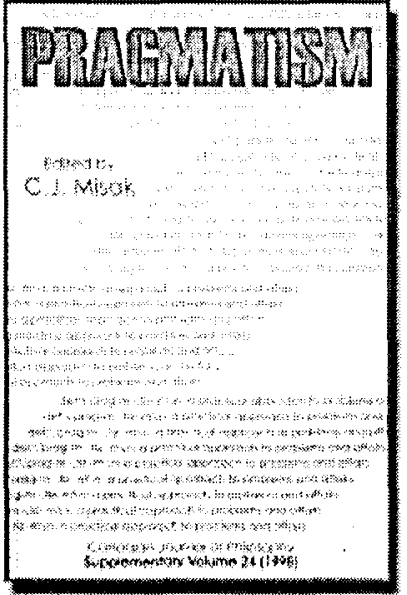

A Fresh Look at Pragmatism

This volume collects some of the very best recent work on pragmatism, the view that philosophical theories must be connected to practical consequences, from both self-styled pragmatists and from those whose positions merely have affinities with pragmatism.

The essays, which cover both classical pragmatism and contemporary approaches, focus on epistemology and moral/political philosophy.

Table of Contents

- Introduction Cheryl Misak

- C.S. Peirce: Belief, Truth, and Going from the Known to the Unknown David Wiggins

- $\quad$ Truth: A Traditional Debate Reviewed Crispin Wright

- $\quad$ Peirce's Double-Aspect Theory of Truth Mark Migotti

- Truth and Ends in Dewey's Pragmatism Henry S. Richardson

- A Pragmatist Theory of Convergence Joseph Heath

- Pragmatism and Change of View Isaac Levi

- Doubt: Affective States and the Regulation of Inquiry Christopher Hookway

- Pragmatism and Moral Knowledge David Bakburst

- Democratic Deliberations, Equality of Influence, and Pragmatism Judith Baker

\section{Order from:}

Raincoast Distribution Services

9050 Shaughnessy Street, Vancouver, BC, V6P 6E5

Telephone: 1-800-663-5714 Fax: 1-800-565-3770

E-mail: custserv@raincoast.com






\section{UNIVERSITY OF CALGARY PRESS}

\section{Meaning and Reference}

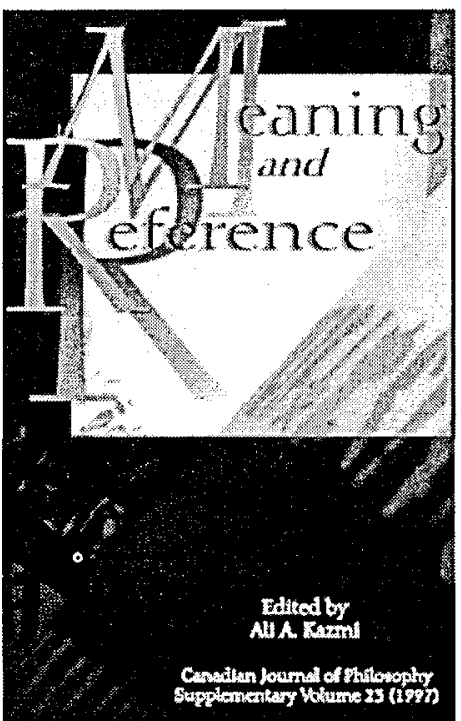

Includes:

Terence Parsons - Missing Modes of Supposition John Burgess - Quinus ab Omni Naevo Vindicatus Richard Cartwright - On Singular Propositions Nathan Salmon - Is de re Belief Reducible to de dicto?

George Wilson - On Some Untamed Anaphora Vann McGee • "Xilimanjaro"

Mark Richard - Inscrutability

Scott Soames - Skepticism about Meaning: Indeterminacy, Normativity, and the Rule-Following Paradox

\section{Kazmi, Ali, editor}

Canadian Journal of Philosophy, Supplementary Volume XXIII (1997)

$\$ 20.00$ (Outside Canada: \$US20.00) ISBN 0-919491-23-5 ISSN 0229-7051 $\mathrm{vi}+260 \mathrm{pp}$. biblio, index $5.5 \times 8.5 \mathrm{in}$.

June 1998

This is a collection of eight new essays by some of the most prominent contemporary philosophers of language. These essays cover a variety of topics including scepticism about meanining and reference, vagueness, rigid designation, $d e$ $r e$ belief, pronominal anaphora, Quinean objections to quantified modal logic, and supposition. This volume will be of interest to anyone who works in the philosophy of language and philosophical logic.

Ali Kazmi is an editor of the Canadian Journal of Philosopby and an associate professor of philosophy at the University of Calgary.

\section{Order from:}

\section{Raincoast Distribution Services}

9050 Shaughnessy Street, Vancouver, BC, V6P 6E5

Telephone: 1-800-663-5714 Fax: 1-800-565-3770

E-mail: custserv@raincoast.com

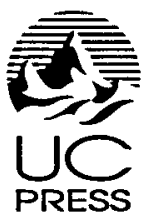




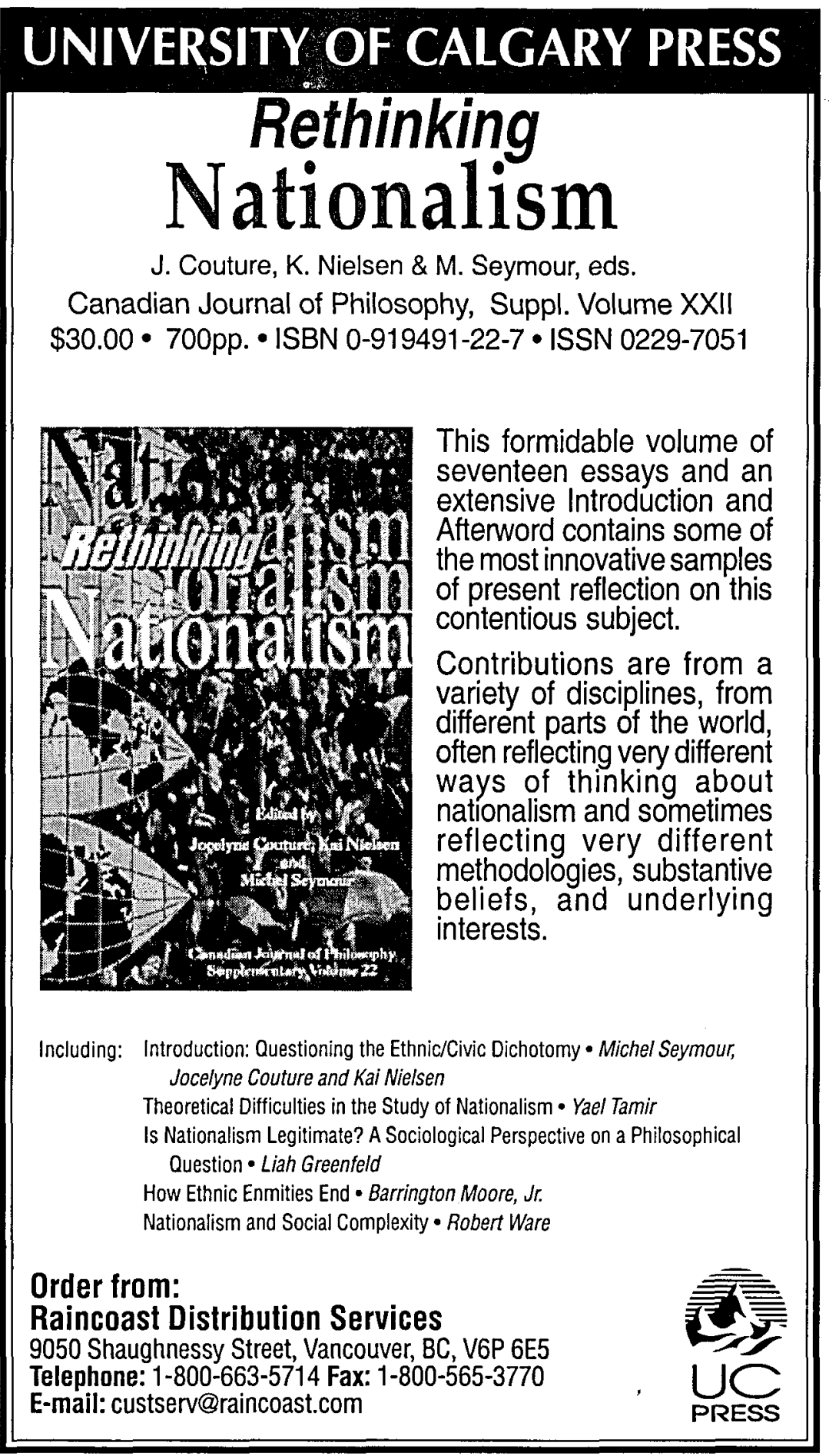




\section{UNIVERSITY OF CALGARY PRESS On the Relevance of Metaethics}

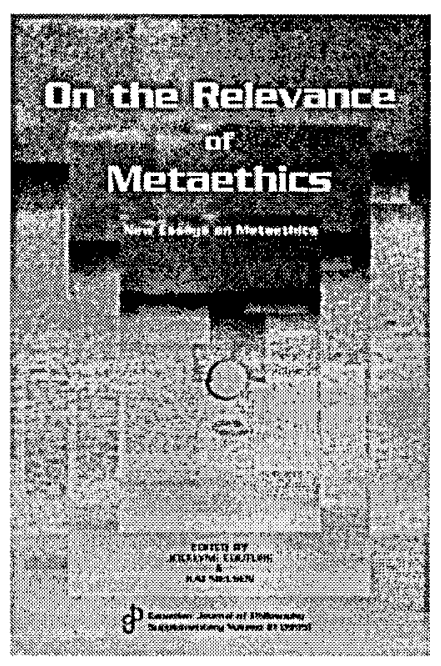

\section{Contents include:}

- Jocelyne Couture and Kai Nielsen Introduction: The Ages of Metaethics - Francis Sparshott

On Metaethics: A Reverie

- Richard B. Brandt

Foundationalism for Moral Theory

- R.M. Hare

Off on the Wrong Foot

- Peter Railton

Made in the Shade: Moral

Compatibilism and the Aims of

Moral Theory

- Jean Hampton

Naturalism and Moral Reasons

- Isaac Levi

Perception as Input and as Reason

for Action
New Essays on Metaethics Jocelyne Couture and

Kai Nielsen, editors

Canadian Journal of Philosophy, Supplementary Volume XXI

$\$ 24.00$ (Outside Canada: \$US24.00) ISBN 0-919491-21-9 ISSN 0229-7051 354 pp., $5.5 \times 8.5$ in.

Around mid-century metaethics held centre stage in discussions of moral philosophy in Anglo-American and Scandinavian philosophical environments. During the 1970s, its "foundational" position was challenged by developments within analytic philosophy itself, by a renewal of systematic substantive ethics largely, but not exclusively, of a Rawlsian inspiration and by a reinvigorated interest in substantive moral problems on the part of philosophers.

However, as work went on here, philosophers encountered problems concerning the methods of moral reasoning and the structure of justification of moral claims that were recognized to be metaethical. This led to a renewal of metaethics now freed from its previously narrow linguistic focus and aprioristic restrictions.

The essays in this volume contribute both to this renewal and to a continued skeptical probing of the very rationale of moral philosophy.

\section{Order from:}

\section{Raincoast Distribution Services}

9050 Shaughnessy Street, Vancouver, BC, V6P 6E5

Telephone: 1-800-663-5714 Fax: 1-800-565-3770

E-mail: custserv@raincoast.com

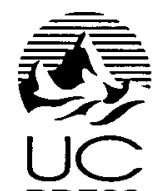

PRESS 







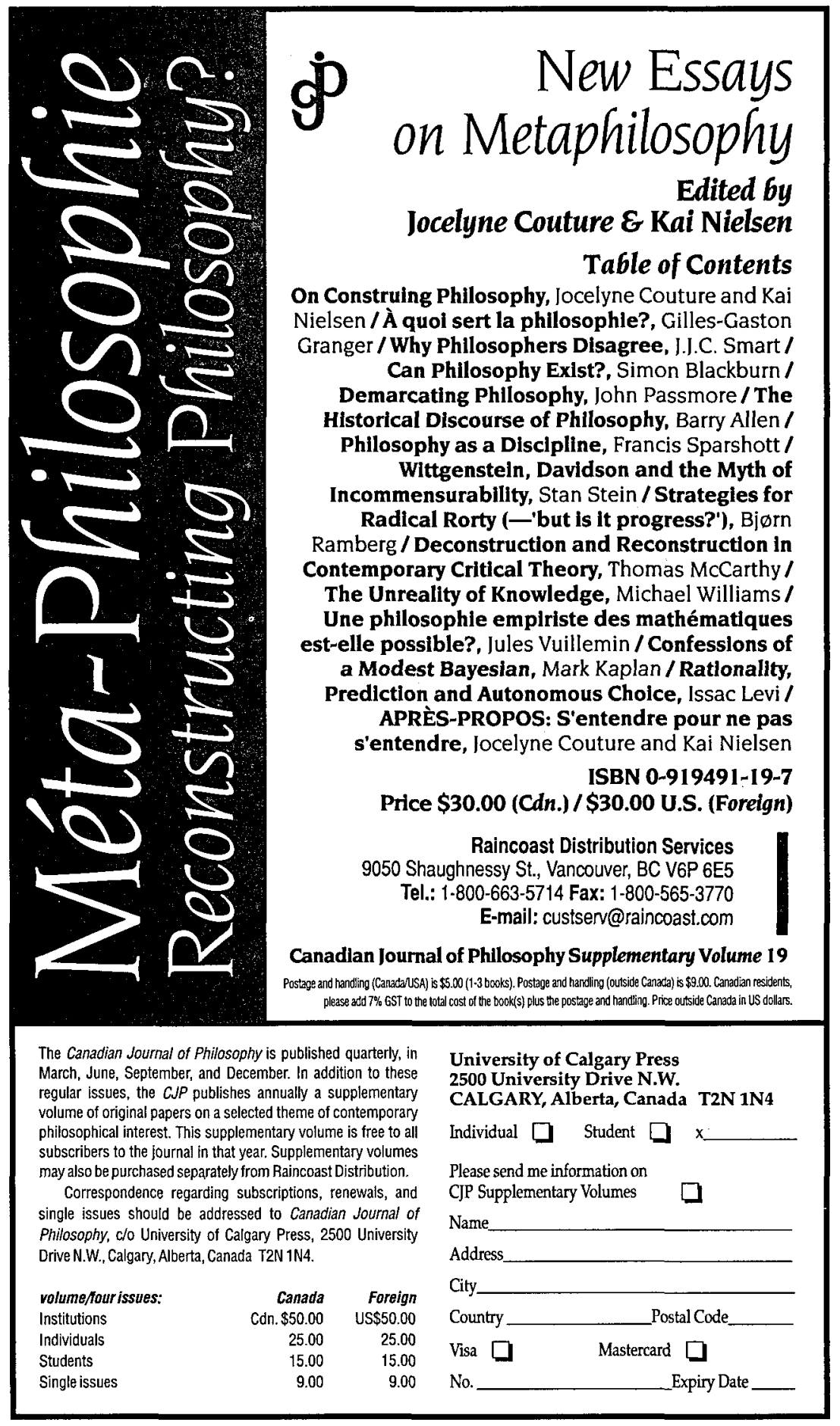




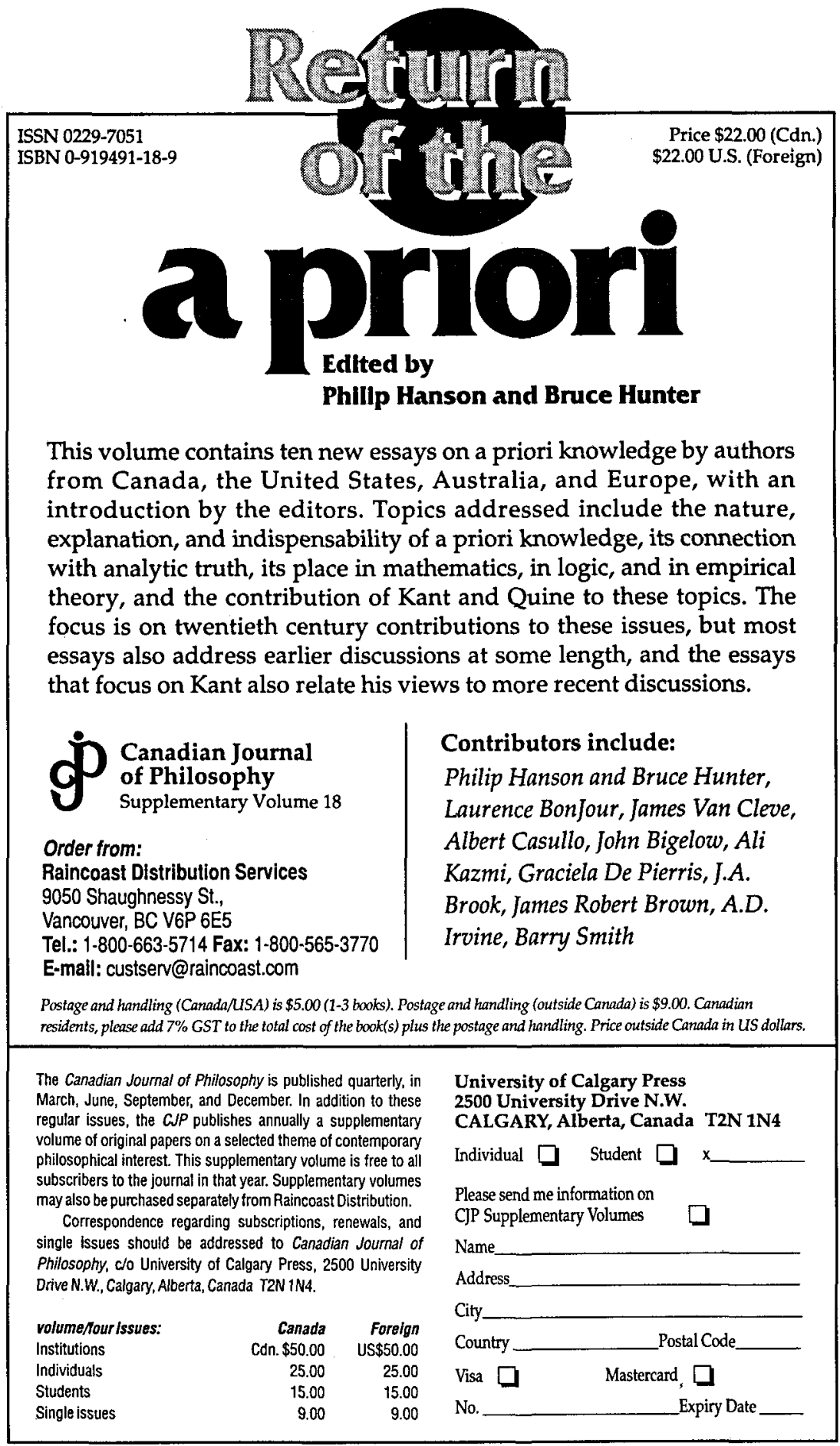




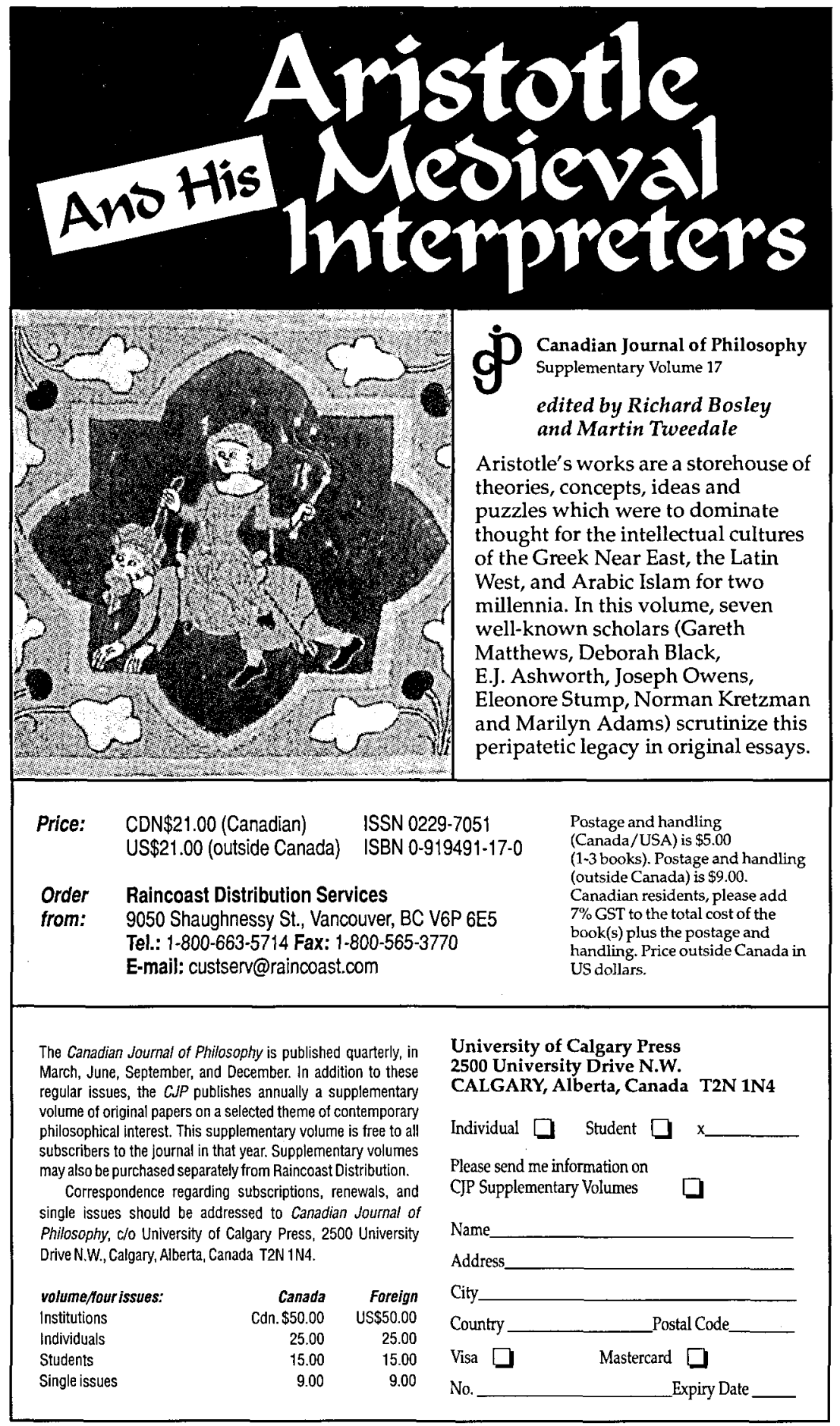




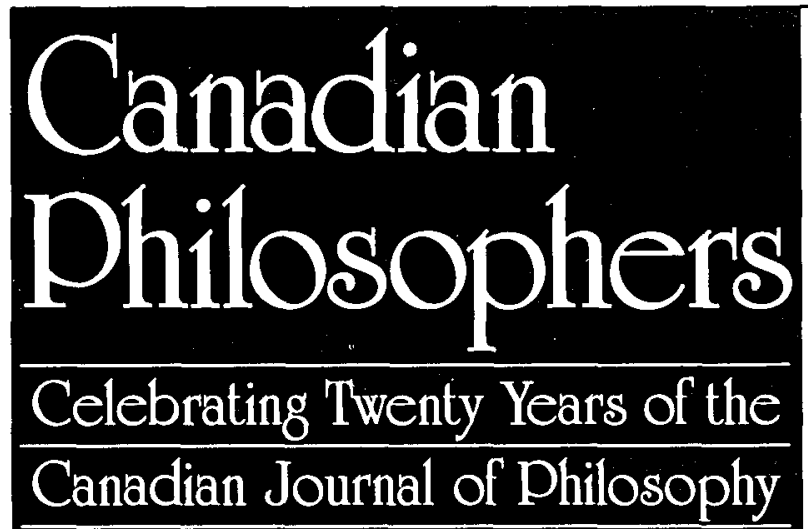

Canadian Journal
of Philosophy
Supplementary
Volume 16

Edited by

David Copp

This collection of original essays celebrates twenty years of the Canadian Journal

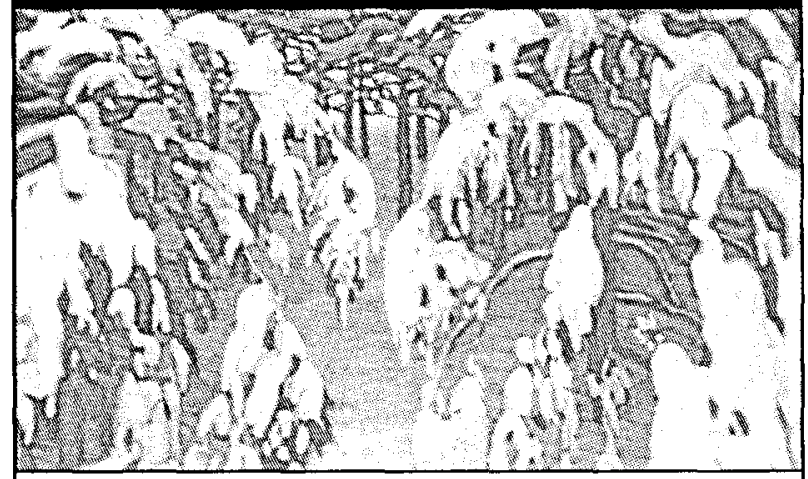

Price:

CDN\$24.00 (in Canada) ISSN 0229-7051

Postage and handling (Canada/USA) is $\$ 5.00$ (1-3 books). Postage US $\$ 20.00$ (outside Canada) ISBN 0-919491-16-2 and handling (outside Canada) is $\$ 9.00$.

Order from:

Raincoast Distribution Services Canadian residents, please add $7 \%$ GST to the total cost of the

9050 Shaughnessy St., Vancouver, BC V6P 6E5

Tel.: 1-800-663-5714 Fax: 1-800-565-3770

book(s) plus the postage and handling.

E-mail: custserv@raincoast.com

Price outside Canada of Philosophy. Contributors include David Gauthier, Terrence M. Penner, Jonathan Bennett, Ann Wilbur MacKenzie, Stephen Yablo, Calvin G. Normore, Ali Akhtar Kazmi, Adam Morton. Michael Tooley, Patricia Smith Churchland, Barry Stroud, G.A. Cohen, and David Braybrooke. David Copp contributes an introduction. in US dollars.

The Canadian Journal of Philosophy is published quarterly, in March, June, September, and December. In addition to these regular issues, the CJP publishes annually a supplementary volume of original papers on a selected theme of contemporary philosophical interest. This supplementary volume is free to all subscribers to the journal in that year. Supplementary volumes may also be purchased separately from Raincoast Distribution.

Correspondence regarding subscriptions, renewals, and single issues should be addressed to Canadian Joumal of Philosophy, c/o University of Calgary Press, 2500 University Drive N.W., Calgary, Alberta, Canada T2N 1 N4.

volume/hour issues:

Institutions

Individuals

Students

Single issues

Canada
Cdn. $\$ 50.00$
25.00
15.00
9.00

Foreign US\$50.00

25.00

15.00 9.00
University of Calgary Press 2500 University Drive N.W.

CALGARY, Alberta, Canada T2N 1N4

Individual Student

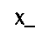

Please send me information on CJP Supplementary Volumes

Name

Address

City

Country Postal Code

Visa

No. Expiry Date 


\section{THE MONIST}

AN INTERNATIONAL JOURNAL OF GENERAL PHILOSOPHICAL INQUIRY

\section{OCTOBER $1999 \diamond \quad$ VOL. 82, NO. $4 \bullet \quad$ SINGLE ISSUE, US $\$ 12$}

\section{COGNITIVE THEORIES OF MENTAL ILLNESS}

\section{ADVISORY EDITOR: JOËLLE PROUST}

ARTICLES

Brendan A. MAher

A. W. Young

Philip Gerrans

John Campbell

KAI Vogeley

Valerie Gray Hardcastle \& OWEN Flanagan

ROBERT L. WOOLFOLK
Anomalous Experience in Everyday Life: Its Significance for Psychopathology

Delusions

Delusional Misidentification as Subpersonal Disintegration

Schizophrenia, the Space of Reasons, and Thinking as a Motor Process

Hallucinations Emerge From an Imbalance of Self-Monitoring and Reality Modelling

Multiplex vs. Multiple Selves:

Distinguishing Dissociative Disorders

Malfunction and Mental lllness

Editor: Barny Smith. University at Buffalo, State University of New York

Single issues, $\$ 12$ postpaid. Annual subscription: institutions, US \$50; individuals, US \$30; make checks payable to THE MONIST, Box 600, La Salle, IL 61301. 


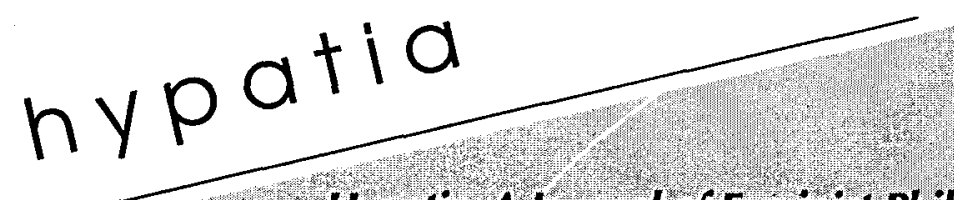

Hypatia: A Journal of Feminist Philosophy

Hypatia is the only journal for scholarly research at the intersection of philosophy and women's studies. GOING AUSTRA IANA:
SMAND PHILOSOPHY Edited by Christine Battersby, Catherine Constable, Rachel lones, and Judy Purdom

Introduction; Learning to Think Intercontinentally Finding Australian Routes" Christine Batters by

CONNECTIONS - INTROOUCTON BV JUDT PURDON

"No One's Land. Australia and the Philosophical Imagination" Genevieve Uloyd The Power of Spinozas Feminist Conjunctions" Susan james talks lo Genevieve Lloyd and Moira Gatens Treminism as 'Password' Rethinking the 'Possible' with Soinoza and Delevze" Moir Catens From Radical Representations to Corporeal Becomings: The Feminist Philosophy of Lloyd, Grosz, and Catens" Claire Colebrook

PROVOCATIONS - INTRODUCTION BY CITHERN CONTARE "Copula. The Logic of the Sexual Relation' Robyn Ferrell What Is ifeminist Philosophy? Rosalyn Diprose "fractured Community Linnell Seconb

TRANSFORNATIONS - INTRODUCTION BY RHCHEL JONB "Imperfect Discretion' Interventions into the History of Philosophy by $20^{\text {th }}$ Century

French Women Philosophers' Penelope Deutscher "Container Technologies" Zoe Sofía Shedding Light on the Matter" Barbara Bolt

Hypatia volume 15, number 2 \$16.95

\section{CONTEMPORARY FRENCH WOMEN PHILOSOPHERS} Edited by Penelope Deutscher

"A Matter of Affect, Passion, and Heart, Our Taste for New Narratives of the History of Philosophy" Penelope Deutscher Introduction to Surla Resistance" Francoise Proust The Line of Resistance" Francoise Proust "Scientific interest: Introduction to Isabelle Stengers, Another Look. Relearning to Laugh". Elizabeth A. Wiscon *Another Look Relearning to Laugh I isabelle Stengers 'Introduction to Tconic Space and the Rule of Lands'" Rico frances Ticonic Space and the Rule of Lands'. Marie-Jose Mondzain "Introduction to Monique David.Menard on Kant and Madness" Alison Ross "Kant's An Essay on the Maladies of the Mind' and Observations on the Feeling of the Beautiful and the sublime" Monique David-Menard

And nuch more

Hypatia volume 15 , number 3 , $\$ 18.95$

Shipping and handling: Add $\$ 5.00$ for one issue and $\$ 1,00$ for each additional Indiana University Press Joumals Division

\section{hypatia:}

a journal of feminist philosophy Edited by Laurie J. Shrage and Nancy Tuana
601 North Morton Street Bloomington, IN 47404

Phonet 1-800-842-6796

Fax: $14812855-8507$

E-mail:joumalseindiana.edu URL wwwiupjournals.org 


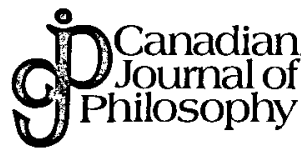

Acknowledge- Canadian Journal of Philosophy is published with the aid of a ments/ grant from the Social Sciences and Humanities Research Council Remerciements of Canada.

La publication du Canadian Journal of Philosophy est rendue possible grâce à une subvention du Conseil de Recherches Humaines du Canada.

Canadian Journal of Philosophy wishes to thank the University of Lethbridge for its generous support for the editorial administration of the journal.

Canadian Journal of Philosophy tient à remercier l'Université de Lethbridge de l'aide généreuse qu'elle apporte à la gestion de sa rédaction.

Canadian Journal of Philosophy is grateful for past support from its originating sponsor, the Canadian Association for Publishing in Philosophy.

Canadian Journal of Philosophy désire exprimer sa gratitude à l'Association Canadienne des Publications en Philosophie qui l'a aide par le passé. 